\title{
Securing a sustainable future for US seafood in the wake of a global crisis
}

\author{
Halley E. Froehlich ${ }^{1}{ }^{*}$, Rebecca Gentry33, Sarah E. Lester ${ }^{3}$, Richard S. Cottrell4, Gavin Fay5, \\ Trevor A. Branch6', Jessica A. Gephart7, Easton R. White ${ }^{8,9}$, Julia K. Baum ${ }^{10}$
}

'Ecology, Evolution, \& Marine Biology, University of California, Santa Barbara, CA, 93106, USA; 2 Environmental Studies, University of California, Santa Barbara, CA, 93106, USA; '3Department of Geography, Florida State University, Tallahassee, FL. USA; 4 National Center for Ecological Analysis and Synthesis, University of California, Santa Barbara, CA, 93101, USA; ${ }^{2}$ Department of Fisheries Oceanography, School for Marine Science and Technology, University of Massachusetts Dartmouth. New Bedford, MA, 02744, USA; 6School of Aquatic and Fishery Sciences, Box 355020, University of Washington, Seattle, WA, 98195, USA; 'Department of Environmental Science, American University, Washington DC 20016; ${ }^{8}$ Department of Biology, University of Vermont, Burlington, VT, 05405, USA; ${ }^{9}$ Gund Institute for Environment, University of Vermont, Burlington, VT, 05405, USA; ${ }^{10}$ Department of Biology, University of Victoria, Victoria, British Columbia, V8W 2Y2, Canada

*Corresponding author: H.E. Froehlich (hefroehlich@ucsb.edu)

\begin{abstract}
The United States seafood industry is undergoing rapid change, as a result of the current trade war with China, ongoing global COVID-19 pandemic, and new governance mandates. The new Executive Order (EO) on Promoting American Seafood Competitiveness and Economic Growth, signed in May 2020, proposes wild-capture fisheries deregulation and prioritization of aquaculture (i.e., aquatic farming), with an emphasis on offshore development. Recent disruption of wild-caught seafood supply and demand could create space for sustainable aquaculture growth, but expansion could also undermine wild fisheries livelihoods and economics if integrated management between industries is ignored. Here, we review the current state of US seafood and outline five guiding principles to better manage US fisheries and aquaculture: (1) make precise and strategic fisheries reforms that continue to support sustainable wild fisheries, (2) integrate aquaculture and fisheries using an ecosystembased approach, (3) address social resistance to aquaculture, (4) improve aquaculture data collection, and (5) reconcile nationalism in a global market. Implementation of these principles is critical for balancing social-ecological trade-offs amongst wild captured and farmed seafood systems, and for ensuring a more resilient US seafood sector under an anticipated future of increased volatility.
\end{abstract}

\section{A system in flux}

The effects of the COVID-19 pandemic are rippling across the world, including the virus hotspot of the United States (Roser et al. 2020). As society and individuals grapple with the physical, psychological, behavioral, and financial toll of this disease, our food systems are experiencing significant changes in the way food is produced, distributed, 
and consumed. US seafood has also experienced major disruptions from the trade war started last year with China-the world's largest seafood consumer (Gephart et al. 2019). These shocks add considerable uncertainty when projecting the impact of recent policy changes, including a sweeping Executive Order to expand American seafood production from capture fisheries and particularly aquaculture (US White House 2020). Together, these impacts and changes present both the opportunity to chart a new trajectory for sustainable US seafood, but also risk destabilizing current trends of sustainability in commercial fisheries. Here, we provide guidance on how to both increase production and also ensure a sustainable future for US seafood as the world slowly emerges from the current crisis.

The effects of the pandemic started early for the US seafood sector (White et al. 2020). A large proportion of value usually stems from restaurant orders $(75 \%)$, which declined dramatically starting in mid-March, co-occurring with reduced or delayed commercial and recreational fishing across most states (Love et al. 2020; White et al. 2020). Similarly, shellfish farmers downsized, and in some cases delayed seeding their crops in hopes of waiting out the decline in demand (Gephart et al. 2020). Many community-supported fisheries (e.g., ("Local Catch Network - LocalCatch.org" 2020) expanded their supplies of diverse seafood direct to local consumers, while larger businesses, such as those producing farmed salmon and trout, rapidly shifted from restaurant to retail sales (Gephart et al. 2020; White et al. 2020). Some aid was made available from the Federal government, but this amounted to only $0.017 \%$ of the $\$ 1.8$ trillion CARES Act (NOAA 2020a).

As the US seafood sector grapples with the myriad of shocks from COVID-19, the ramifications of the Executive Order (US White House 2020) signed in early May are uncertain. Here, we briefly describe the current state of US seafood and provide five guiding principles for the implementation of the Order's mandates to facilitate a pathway towards sustainable and economically prosperous fisheries and aquaculture in the US:

1. Make precise and strategic fisheries reforms

2. Integrate fisheries \& aquaculture through an ecosystem-based approach

3. Explicitly address social resistance to aquaculture

4. Collect more comprehensive aquaculture data

5. Reconcile nationalism in a global market

\section{Current state of US fisheries and aquaculture}

Before the pandemic, annual domestic seafood production in the United States was approximately 5.5 million tonnes, but the US is the largest net seafood importer in the world, with a growing "trade deficit" and an import seafood dependence of $62-65 \%$ (Gephart et al. 2019)—one of the key motivations listed for the Executive Order. The vast majority (>90\%) of domestic production comes from wild capture fisheries (Figure 1), which are now some of the most sustainably managed natural resources globally, 
although there is limited scope for additional wild harvest (Hilborn et al. 2020). The national aquaculture sector plays a much smaller role, contributing just $8 \%$ of all domestic production in recent years (Figure 1). Marine aquaculture, particularly offshore (3-200 $\mathrm{nm}$ from the coast), is increasingly identified as an area where the US could support substantial seafood growth (Gentry et al. 2017; Lester et al. 2018). Americans certainly have an appetite for farmed seafood: three of the top four consumed taxa are mostly farmed, but are primarily raised in other countries: salmon (global farmed ratio $=2.7: 1$ ), shrimp (3:1), and tilapia (8.3:1) (FAO 2020). These consumption patterns create important social and environmental tradeoffs that have led to calls for more domestic production and improvements in trade policies to support sustainable practices. The complex suite of agencies and regulations governing aquaculture are often blamed for the slow growth of aquaculture in the US (DeVoe 1999; Cicin-Sain et al. 2001; Lester et al. 2018; Sea Grant 2019), and the need for aquaculture policy reform has been garnering increasing attention from the Federal (e.g., (Wicker 2018), State, and local governments.

\section{Executive Order: a changing tide for the US seafood industry}

The May 7, 2020 Executive Order on Promoting American Seafood Competitiveness and Economic Growth asserts a broad initiative to increase US seafood production, with a particular focus on offshore aquaculture (US White House 2020). Of note, the Order designates NOAA as the lead governing agency for aquaculture in addition to its current mandate over fisheries. With timelines

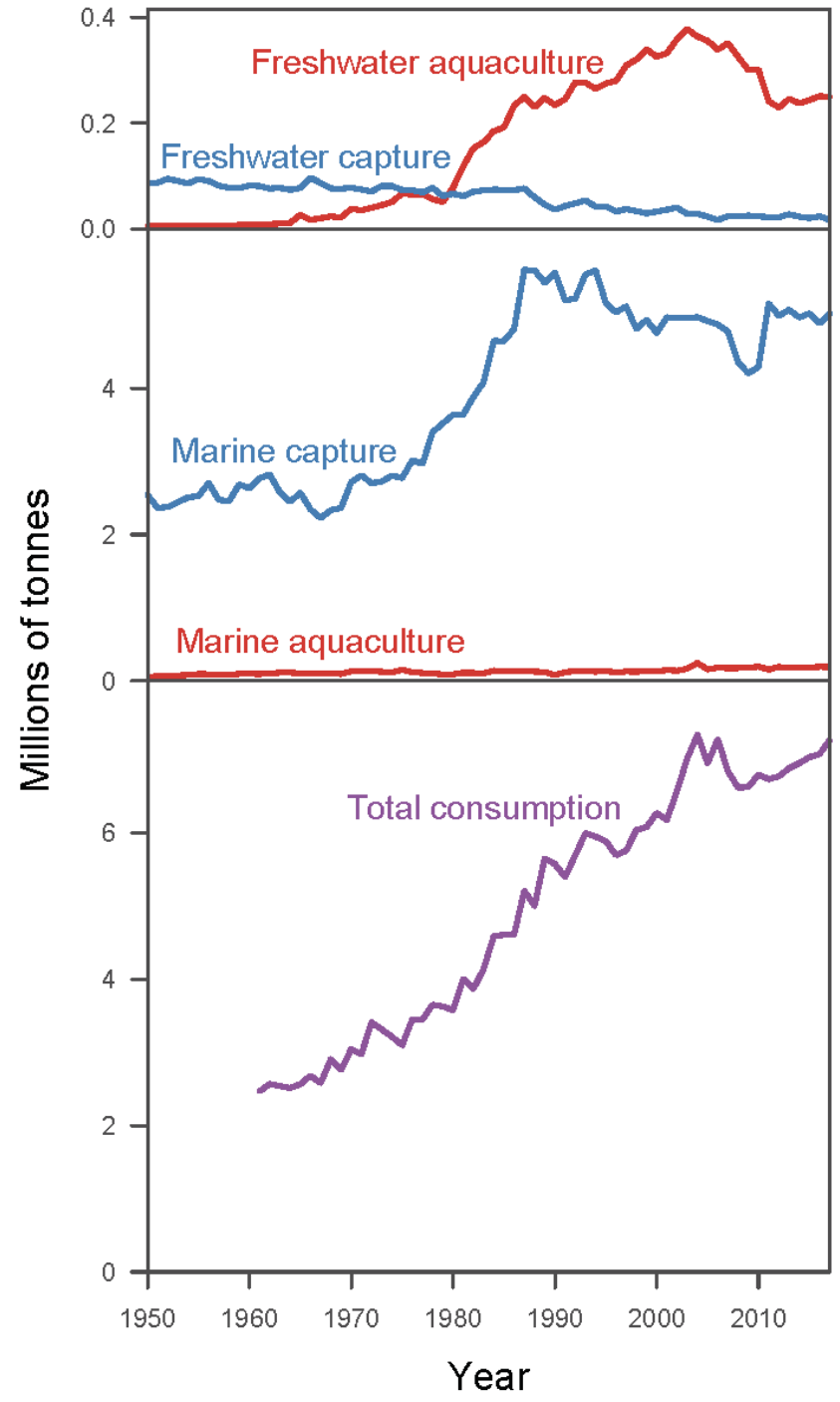

Figure 1. Estimated United States aquaculture and wild capture seafood production over time (1950-2017), for freshwater (top) and marine systems (middle), and total combined domestic seafood consumption, which accounts from imports and exports of wild capture and aquaculture products combined (bottom). Data include finfish, molluscs, crustaceans, and aquatic plants (FAO 2020). ranging from months to several years, Federal and State agencies are being asked to reassess how commercial fisheries are managed, create standardized and predictable aquaculture permitting, revise trade policy through a Seafood Trade Task Force, and 
update aquatic animal health regulation. To promote offshore aquaculture expansion, NOAA is tasked with identifying four offshore areas over the next five years for finfish, seaweed, or integrated aquaculture production. It is within this context that we suggest these guiding principles.

\section{Make precise and strategic fisheries reforms}

The Executive Order includes a directive to "reduce burdens on domestic fishing and to increase production," while maintaining sustainability as defined by Magnuson-Stevens Fishery Conservation and Management Act (MSFCMA) and Marine Mammal Protection Act (MMPA). Increasing production of wild-caught fish would be difficult, since a high fraction (85\%) of US assessed stocks are fished at or near maximum sustainable levels (Gephart et al. 2019). Many fisheries have layers of regulations that both directly limit total allowable catch and control where, when, and how fish are caught. It may be possible to reduce some of the latter regulations, while retaining catch limits, and still ensure fisheries remain ecologically and economically sustainable. Changes might include modified gear type restrictions for better control over which species are caught, increased flexibility for switching fisheries or gears (Kroetz et al. 2019), and changes to how quota is allocated among fisheries sectors. Additionally, in some fisheries, the government could shoulder observer costs, or shift from on-board observers to electronic (video) monitoring. In many cases, cost-effective burden reductions could be achieved through more accurate scientific estimates of fish trends and status through scientific surveys and stock assessments that better account for and respond to changing productivity, to reduce overall fishery constraints caused by precautionary (low) catch limits on some species. The current US Administration has also implemented a separate EO, opening marine national monuments to fishing, even though the gains from this action are likely to be small (Gephart et al. 2019) and counterproductive. Any reductions in fisheries regulations need to be tested to ensure they do not threaten fisheries sustainability, and it should be recognized that such changes are likely to improve profitability but may not greatly increase wild production (Figure 2).

\section{Integrating aquaculture \& fisheries through an ecosystem-based approach}

There is potential for better integrated management for US wild capture fisheries and aquaculture (Figure 2). The two sectors are mostly managed separately, even though they interact directly and indirectly in space, through feed, seed, and markets (Clavelle et al. 2019). Separate management approaches may be a function of the previous lead agency for aquaculture being the Department of Agriculture. However, now with NOAA designated as lead, there is stronger potential to align principles from Ecosystembased Fisheries Management (EBFM) (Dolan et al. 2016; Marshall et al. 2018) and the Ecosystem Approach to Aquaculture (EAA) (Soto et al. 2008; Brugère et al. 2019) (Figure 2). The opportunity to build a sustainable management framework which more explicitly 
integrates fisheries and aquaculture, alongside community well-being and environmental health, is not a stretch given that aspects of EBFM and EAA are already in use in their respective sectors. Such coordination is crucial given that well-managed and spatially planned marine aquaculture can reduce environmental impacts, but poorly managed operations can degrade the health of stocks-wild and farmed-and the ecosystem (Clavelle et al. 2019). Reflecting on domestic and international ecosystem goals (notably the UN Sustainable Development Goals), improving understanding of demand for alternative seafood species, and identifying the role the US should play in developing sustainable standards and practices for wild fisheries and aquaculture will help assess the value and limits of seafood expansion in the US (Figure 2).

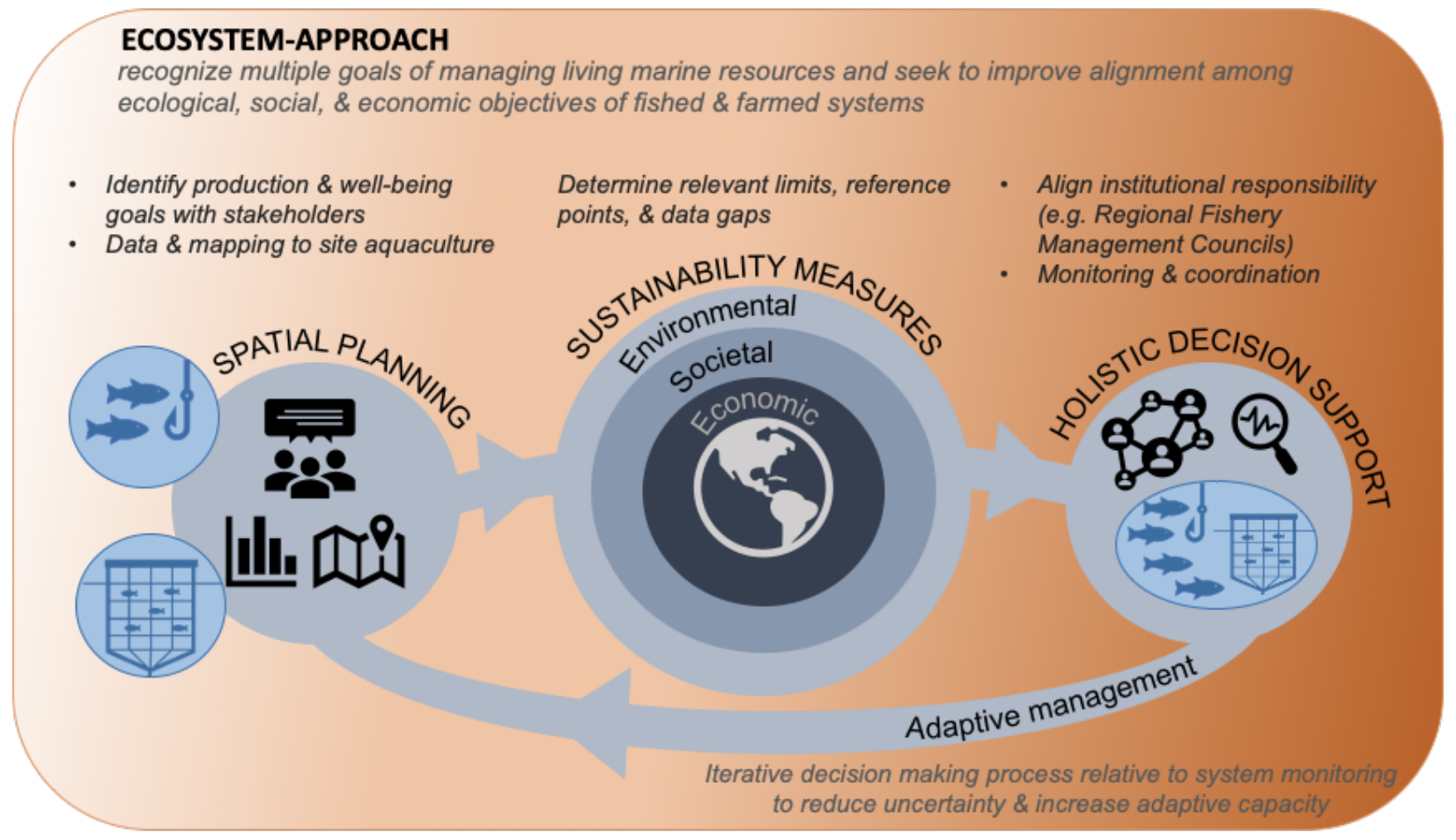

Figure 2. Applying an ecosystem-based approach to explicitly integrate aquaculture and fisheries management.

\section{Explicitly address social resistance to aquaculture}

Even with stronger political and regulatory support, aquaculture expansion may be hampered by a lack of social acceptance and communities reluctant to support local aquaculture development (Froehlich et al. 2017). This is in spite of the high US consumption of imported farmed seafood. North Americans eat seafood primarily based on product recognition, taste, and price (Murray et al. 2017) and there is no guarantee communities will support local aquaculture development. Indeed, domestic efforts around marine aquaculture development have experienced strong opposition, 
including in the Gulf of Mexico and Washington state (Froehlich et al. 2017). This underscores that if local stakeholders are not involved in the process of new aquaculture development, the Executive Order and other efforts might do little to push aquaculture forward domestically. As in fisheries and ecosystem-based management approaches, accounting for social "carrying capacity" is critical. Good site selection through spatial planning is essential to minimize social objections, conflicts with other ocean uses, and decrease risks, central to an ecosystem-based approach (Figure 2). NOAA is now well positioned to support these goals given their lead role in fisheries and marine aquaculture, as well as their continued progress in national spatial data resources and planning (e.g., (NOAA 2020) (Figure 2).

\section{Collect more comprehensive aquaculture data}

Another important component of the Executive Order-in line with fisheries management requirements -is "suitable reporting" by owners and operators of US aquaculture. Currently, production reporting is not standardized and largely determined state-by-state, while Federal reporting happens at 5-year census increments (USDA 2020). Annual production and on-farm metrics (e.g., efficiencies, feed source/amount, survival, environmental measures, etc.) should be standardized so the state and federal agencies can accurately track production and environmental goals (Figure 2). In the midst of the pandemic, uncertainty in aquaculture location and scale can create confusion and inequities in relief funding allocation. Moreover, improved data are essential to assess ecosystem farming impacts, effects of the environment versus husbandry on production, and the risk and variability of long-term production, all of which can improve confidence for insurance agencies, investors, and the public. It is difficult to set sustainable seafood targets and build resilience with highly uncertain data (Figure 2). That said, data-driven transparency platforms and technology are gaining some momentum in aquaculture (e.g., (Davé 2020) and ideally would be supported by the government.

\section{Reconcile nationalism in a global market}

The COVID-19 pandemic's disruption of food supply chains has highlighted the risks of reliance on foreign imports for food, which may advance more nationalistic food strategies. Yet, focusing on the US seafood deficit must be reconciled with the Order's objective of identifying "opportunities to improve access to foreign markets" and the reality of a highly globalized seafood market. Seafood is among the most highly traded food commodities in the world (Gephart et al. 2019), and the US is both the top importer and among the top five exporters of seafood (Gephart \& Pace 2015; FAO 2020). Yet, past efforts to make US farmed seafood competitive with foreign farmed products through labelling and trade barriers, have been largely unsuccessful. For example, the US imposed tariffs of $63 \%$ on Vietnamese catfish imports, implemented more rigorous import inspections, and passed a law to prevent labelling Asian catfish as 
catfish (Margolis 2018). Despite the extreme measures, Vietnamese catfish imports have grown, while US catfish sales have remained relatively flat (USDA 2020). Further,

imposing import restrictions comes at a cost to consumers and results in challenges to the World Trade Organization and retaliatory tariffs by exporting nations, which hamper efforts to develop foreign markets for US seafood. In the long term, the combined effects of pandemic-related trade disruptions and questions about whether the US is a reliable trade partner may hamper the goal of improving access to foreign seafood markets. The Seafood Trade Task Force should therefore not only consider technical challenges (e.g., (NOAA 2020b), but also paths to ensure trade partner confidence in US export reliability. In doing so, the US can maintain and support the expansion of sustainable domestic seafood producers in high value foreign markets.

\section{Conclusions}

During this period of turmoil, uncertainty, and rapid policy change, it will be a challenge to develop institutions and governance that can guide American seafood towards a sustainable future that supports economic development, healthy oceans, and food security. However, we can maintain the sustainability of wild capture fisheries while expanding domestic marine aquaculture, if the two seafood sectors are managed integratively using ecosystem-based approaches. This will depend on recognition of the importance of seafood in our coastal communities and for the well-being of our country as a whole. Continued reliance on the best available science and improved monitoring are crucial to help assess how specific policies can be achieved in concert with system-wide management to benefit society and the environment. Early and continued consultation with coastal communities and all stakeholders must be recognized as a key component in striking this balance. Further, we must accept that change may become more common as we look into a future of climatic and political instability. Flexibility and adaptive capacity within our institutions and participation in global trade can add resiliency to our seafood systems so that we can collectively survive, and ideally thrive into the future.

\section{References}

Brugère, C., Aguilar-Manjarrez, J., Beveridge, M.C.M. \& Soto, D. (2019). The ecosystem approach to aquaculture 10 years on - a critical review and consideration of its future role in blue growth. Reviews in Aquaculture, 11, 493-514.

Cicin-Sain, B., Bunsick, S.M., DeVoe, R., Eichenberg, T., Ewart, J., Halvorson, H., Knecht, R.W. \& Rheault, R. (2001). Development of a policy framework for offshore marine aquaculture in the 3-200 mile US ocean zone. University of Delaware, Center for the Study of Marine Policy.

Clavelle, T., Lester, S.E., Gentry, R. \& Froehlich, H.E. (2019). Interactions and management for the future of marine aquaculture and capture fisheries. Fish and Fisheries, 0.

Davé, N. (2020). Introducing Tidal - X, the moonshot factory [WWW Document]. Tidal. URL https://blog.x.company/introducing-tidal-1914257962c3 
DeVoe, M.R. (1999). Marine aquaculture in the United States: Current and future policy and management challenges. Trends and future challenges for US National ocean and coastal policy. National Oceanic and Atmospheric Administration, Silver Spring, MD, 85-93.

Dolan, T.E., Patrick, W.S. \& Link, J.S. (2016). Delineating the continuum of marine ecosystem-based management: a US fisheries reference point perspective. ICES J Mar Sci, 73, 1042-1050.

FAO. (2020). The State of World Fisheries and Aquaculture 2020: Sustainability in action. The State of World Fisheries and Aquaculture (SOFIA). FAO, Rome, Italy.

Froehlich, H.E., Gentry, R.R., Rust, M.B., Grimm, D. \& Halpern, B.S. (2017). Public Perceptions of Aquaculture: Evaluating Spatiotemporal Patterns of Sentiment around the World. PLOS ONE, 12, e0169281.

Gentry, R.R., Froehlich, H.E., Grimm, D., Kareiva, P., Parke, M., Rust, M., Gaines, S.D. \& Halpern, B.S. (2017). Mapping the global potential for marine aquaculture. Nature Ecology \& Evolution, 1.

Gephart, J.A., Froehlich, H.E. \& Branch, T.A. (2019). Opinion: To create sustainable seafood industries, the United States needs a better accounting of imports and exports. PNAS, 116, 9142-9146.

Gephart, J.A. \& Pace, M.L. (2015). Structure and evolution of the global seafood trade network. Environ. Res. Lett., 10, 125014.

Gephart, J.A., Richard S. Cottrell, Halley Froehlich, Elizabeth Nussbaumer, Joshua S. Stoll \& Easton White. (2020). Covid-19 Seafood Impacts.

Hilborn, R., Amoroso, R.O., Anderson, C.M., Baum, J.K., Branch, T.A., Costello, C., Moor, C.L. de, Faraj, A., Hively, D., Jensen, O.P., Kurota, H., Little, L.R., Mace, P., McClanahan, T., Melnychuk, M.C., Minto, C., Osio, G.C., Parma, A.M., Pons, M., Segurado, S., Szuwalski, C.S., Wilson, J.R. \& Ye, Y. (2020). Effective fisheries management instrumental in improving fish stock status. PNAS.

Kroetz, K., Reimer, M.N., Sanchirico, J.N., Lew, D.K. \& Huetteman, J. (2019). Defining the economic scope for ecosystem-based fishery management. PNAS, 116, 41884193.

Lester, S.E., Gentry, R.R., Kappel, C.V., White, C. \& Gaines, S.D. (2018). Opinion: Offshore aquaculture in the United States: Untapped potential in need of smart policy. PNAS, 115, 7162-7165.

Local Catch Network - LocalCatch.org [WWW Document]. (2020). . URL https://localcatch.org/

Love, D.C., Asche, F., Conrad, Z., Young, R., Harding, J., Nussbaumer, E.M., ThorneLyman, A.L. \& Neff, R. (2020). Food Sources and Expenditures for Seafood in the United States. Nutrients, 12, 1810.

Margolis, J. (2018). The US and Vietnam continue their 17-year-old trade dispute over catfish [WWW Document]. The World. URL https://www.pri.org/stories/2018-0425/great-catfish-war-rages

Marshall, K.N., Koehn, L.E., Levin, P.S., Essington, T.E. \& Jensen, O.P. (2018). Inclusion of ecosystem information in US fish stock assessments suggests progress toward ecosystem-based fisheries management. ICES Journal of Marine Science. 
Murray, G., Wolff, K. \& Patterson, M. (2017). Why eat fish? Factors influencing seafood consumer choices in British Columbia, Canada. Ocean \& Coastal Management, $144,16-22$.

NOAA. (2020a). NOAA Fisheries Coronavirus (COVID-19) Update | NOAA Fisheries [WWW Document]. NOAA Fisheries. URL https://www.fisheries.noaa.gov/national/noaa-fisheries-coronavirus-covid-19update

NOAA. (2020). OceanReports [WWW Document]. NOAA Office for Coastal Management. URL https://coast.noaa.gov/digitalcoast/tools/ort.html

NOAA. (2020b). U.S. Seafood Import Monitoring Program [WWW Document]. National Ocean Council Committee on IUU Fishing and Seafood Fraud. URL https://www.iuffishing.noaa.gov/RecommendationsandActions/RECOMMENDA TION1415/FinalRuleTraceability.aspx

Roser, M., Ritchie, H., Ortiz-Ospina, E. \& Hasell, J. (2020). Coronavirus Pandemic (COVID19). Our World in Data.

Sea Grant. (2019). Overcoming Impediments to Shellfish Aquaculture through Legal Research and Outreach: Case Studies. Sea Grant Law.

Soto, D., Aguilar-Manjarrez, J., Hishamunda, N. \& others. (2008). Building an ecosystem approach to aquaculture. FAO/Universitat de les llles Balears Expert Workshop. 7û1 1 May 2007, Palma de Mallorca, Spain.

US White House. (2020). Executive Order on Promoting American Seafood Competitiveness and Economic Growth [WWW Document]. The White House. URL https://www.whitehouse.gov/presidential-actions/executive-orderpromoting-american-seafood-competitiveness-economic-growth/

USDA. (2020). USDA/NASS QuickStats Ad-hoc Query Tool [WWW Document]. URL https://quickstats.nass.usda.gov/results/CA62A751-1DF1-3148-8738AEEE6A0F54C2

White, E.R., Froehlich, H.E., Gephart, J.A., Cottrell, R.S., Branch, T.A. \& Baum, J.K. (2020). Early effects of COVID-19 interventions on US fisheries and seafood (preprint). Open Science Framework. 10.31219/osf.io/9bxnh

Wicker, R.F. (2018). S.3138 - 115th Congress (2017-2018): AQUAA Act [WWW Document]. URL https://www.congress.gov/bill/1 15th-congress/senate-bill/3138

\section{Acknowledgements}

H.E.F. recognizes support from the University of California, Santa Barbara. E.R.W. was supported by the COVID-19 Rapid Research Fund from the Gund Institute for Environment at the University of Vermont. T.A.B. was partly funded through Richard C. and Lois M. Worthington Endowed Professor in Fisheries Management. S.E.L and R.R.G. acknowledge funding from NSF grant 1759559 and NOAA Sea Grant [NA19OAR4170346] with H.E.F. R.S.C acknowledges support from the National Center for Ecological Analysis and Synthesis, University of California, Santa Barbara. J.K.B. acknowledges support from an NSERC Discovery Grant and EWR Steacie Fellowship. 


\section{Conflicts of Interest}

HEF: Technical Scientific Advisory Group for the Aquaculture Stewardship Council; GF: Mid-Atlantic Fishery Management Council Scientific and Statistical Committee, New England Fishery Management Council Ecosystem-Based Fishery Management Plan Development Team. Have received funding from Government fisheries agencies and management authorities and fishing industry. 